\title{
Acta
Biochimica
Polonica
}

Vol. 46 No. $4 / 1999$

862-872

QUARTERLY

\section{Involvement of the essential yeast DNA polymerases in induced gene conversion ${ }^{\circ}$}

\author{
Agnieszka Hałas ${ }^{\rrbracket}$, Arkadiusz Ciesielski and Jerzy Żuk \\ Institute of Biochemistry and Biophysics, Polish Academy of Sciences, A. Pawiniskiego 5a, \\ 02-106 Warszawa, Poland
}

Received: 21 October, 1999

Key words: DNA polymerases, gene conversion, Saccharomyces cerevisiae

In the yeast Saccharomyces cerevisiae three different DNA polymerases $\alpha, \delta$ and $\varepsilon$ are involved in DNA replication. DNA polymerase $\alpha$ is responsible for initiation of DNA synthesis and polymerases $\delta$ and $\varepsilon$ are required for elongation of DNA strand during replication. DNA polymerases $\delta$ and $\varepsilon$ are also involved in DNA repair. In this work we studied the role of these three DNA polymerases in the process of recombinational synthesis. Using thermo-sensitive heteroallelic mutants in genes encoding DNA polymerases we studied their role in the process of induced gene conversion. Mutant strains were treated with mutagens, incubated under permissive or restrictive conditions and the numbers of convertants obtained were compared. A very high difference in the number of convertants between restrictive and permissive conditions was observed for polymerases $\alpha$ and $\delta$, which suggests that these two polymerases play an important role in DNA synthesis during mitotic gene conversion. Marginal dependence of gene conversion on the activity of polymerase $\varepsilon$ indicates that this DNA polymerase may be involved in this process but rather as an auxiliary enzyme.

In the yeast Saccharomyces cerevisiae three different DNA polymerases: polymerase $\alpha$ (I), polymerase $\varepsilon$ (II) and polymerase $\delta$ (III) are essential for DNA replication (Bauer et al., 1988; Boulet et al., 1989; Sitney et al., 1989; Hamatake et al., 1990; Morrison et al., 1990; Araki et al., 1992). Polymerase $\alpha$ is physically associated with DNA primase and is believed to extend RNA primers during initiation of replication (Foiani et al., 1994). Polymerases $\delta$ and $\varepsilon$ are responsible for DNA elongation (Budd \& Campbell, 1993; Budd \& Campbell, 1997).

DNA polymerase activity is also necessary for DNA repair. The role of distinct polymerases in different DNA repair pathways -

\footnotetext{
This work was supported by the State Committee for Scientific Research, grant No. PO4A03811 and in part grant No. 6PO4A03809.

${ }^{8}$ Corresponding author: Agnieszka Hałas: phone: (48 22) 6597072 ext. 1314; fax: (48) 3912 1623;

e-mail: aga214@ibbrain.ibb.waw.pl

Abbreviations: MMS, methylmethanesulphonate; TMP, 4,5',8-trimethylpsoralen.
} 
base excision repair (BER) and nucleotide excision repair (NER) in yeast has been established in vivo (Budd et al., 1989; Suszek et al., 1993; Blank et al., 1994; Leem et al., 1994; Budd \& Campbell, 1995; Hałas et al., 1997) and in vitro (Wang et al., 1993).

Gene conversion is another process in which DNA polymerase activity is necessary. In all known models of recombination, this activity is required for the extension of strand displacement and for repair synthesis of the remaining gaps (Meselson \& Radding, 1975; Szostak et al., 1983). It is also needed for mismatch repair of heteroduplex DNA which eventually leads to gene conversion.

Until now only the role of DNA polymerase $\delta$ on gene conversion has been investigated (Fabre et al., 1991). Since the thermosensitive noncomplementing heteroallelic mutants for all essential DNA polymerases are now available, we expand the experiment presented by Fabre et al. (1991) to two other essential DNA polymerases $\alpha$ and $\varepsilon$, using the same rationale of the experiment.

In our previous works we showed that DNA polymerase $\varepsilon$ is responsible for the repair of lesions caused by UV radiation, but does not repair methylmethanesulphonate-induced breaks (Hałas et al., 1997; 1999). Polymerase $\delta$ catalyses the repair synthesis of DNA damaged by UV (Budd \& Campbell, 1995) as well as MMS (Suszek et al., 1993; Blank et al., 1994; Hałas et al., 1997). Therefore, it seems that DNA polymerases may have different specificity towards particular types of DNA damages. To check if a similar difference may also be observed in induced gene conversion, we performed our experiments with different kinds of mutagenic agents: UV, MMS and psoralens.

\section{MATERIALS AND METHODS}

Strains and media. The original pol1 and pol2 haploid strains were kindly provided by
Dr. J.L. Campbell and pol3 (cdc2) mutants were a gift from Dr. C.S. Newlon.

Using haploid strains we constructed diploids, heteroallelic in genes encoding three different DNA polymerases:

- HB104 for polymerase $\alpha$ (POL1)

a/ $\alpha$ trp1-289/trp1-289 ade2-101/ade2-101 ura3-1,2/ura3-1,2 tyr1/tyr1 pol1-14/pol1-17

-AK4 for polymerase $\varepsilon$ (POL2) a/ $\alpha$ trp1-289/TRP ade2-101/ADE ura3-1,2/ ura3-52 tyr1/TYR pol2-12/pol2-11

HB69 for polymerase $\delta$ (POL3) a/ $\alpha$ ura1/ura1 ade1,ade2/ade lys $2 / L Y S$ tyr1/ TYR his7/his7 gal1/GAL cdc2-3/cdc2-1

The growth medium was YPD (Sherman et al., 1974).

Experimental procedure. Cells were grown to stationary phase $\left(\mathrm{G}_{0}\right)$ in liquid YPD at the permissive temperature $23^{\circ} \mathrm{C}$ for $48 \mathrm{~h}$ with aeration. Cells were harvested by centrifugation, washed with $0.1 \mathrm{M}$ phosphate buffer, $\mathrm{pH} 7$, and resuspended in the same buffer at a concentration of $1-2 \times 10^{8}$ cells/ $\mathrm{ml}$. Cells were treated with mutagen and plated on YPD in two groups. The cells from the first group were plated on prewarmed $\left(38^{\circ} \mathrm{C}\right)$ YPD plates and grown in restrictive conditions $\left(38^{\circ} \mathrm{C}\right)$ for selection of wild type recombinants in genes encoding the investigated DNA polymerases (POL1, POL2, $P O L 3)$. Plates from the second group were preincubated $6 \mathrm{~h}$ in permissive conditions $\left(23^{\circ} \mathrm{C}\right)$ before shifting to $38^{\circ} \mathrm{C}$ to apply selection after at least one round of DNA replication. Recombinants were counted after 3 days.

\section{Mutagen treatment}

UV irradiation. Aliquots of $0.1 \mathrm{ml}$ of undiluted suspension of cells were plated on YPD plates and irradiated immediately with UV HN530 Osram Lamp (254 nm; $1.5 \mathrm{~J} / \mathrm{m}^{2}$ ) with doses up to $37.5 \mathrm{~J} / \mathrm{m}^{2}$.

Methylmethanesulphonate (MMS) treatment. Cells were treated with $0.25 \%$ MMS 
(Merck) (Suszek et al.,1993) for up to $25 \mathrm{~min}$ and plated on YPD as described above.

4,5',8-trimethylpsoralen (TMP) treatment. Cells were treated with $4 \mu \mathrm{l}$ saturated ethanol solution of TMP (Sigma) per $1 \mu \mathrm{l}$ of cell suspension for $1 \mathrm{~h}$ on ice, irradiated with Universal-UV-Lamp Camag ( $366 \mathrm{~nm} ; 2 \mathrm{~J} / \mathrm{m}^{2}$ ) with dose up to $150 \mathrm{~J} / \mathrm{m}^{2}$ and plated in two groups on YPD as described earlier.

Psoralen treatment. Cells were treated with $10 \mu \mathrm{l}$ saturated ethanol solution of psoralen per $1 \mathrm{ml}$ of cell suspension for $1 \mathrm{~h}$ on ice, irradiated with Universal-UV-Lamp Camag ( $366 \mathrm{~nm} ; 2 \mathrm{~J} / \mathrm{m}^{2}$ ) with a dose up to 300 $\mathrm{J} / \mathrm{m}^{2}$ and plated on YPD as above.

To determine the survival of cells after mutagen treatment, diluted aliquots were plated on YPD and incubated at permissive temperature $\left(23^{\circ} \mathrm{C}\right)$. The colonies were counted after three days.

All platings were in triplicate and the experiments were repeated at least twice.

\section{DNA synthesis}

The stationary phase $\left(\mathrm{G}_{0}\right)$ cells were centrifuged and resuspended in YPD medium diluted 10-fold with $2 \%$ glucose and supplemented with $0.5 \mu \mathrm{Ci} / \mathrm{ml}$ of $\left[2{ }^{14} \mathrm{C}\right]$ uracil (Amersham U.K.) for DNA labelling. The suspension of labelled cells was divided into two groups. The first one was treated with $\mathrm{NaOH}$ to final concentration $0.3 \mathrm{M} \mathrm{NaOH}$, and incubated at $30^{\circ} \mathrm{C}$ overnight to hydrolyse RNA. The second group was first incubated for $6 \mathrm{~h}$ at $23^{\circ} \mathrm{C}$ and then treated with $\mathrm{NaOH}$ as described above. The samples was chilled on ice, precipitated with $25 \%$ trichloroacetic acid (TCA), collected on glass-fibre filters and counted in toluene based scintillation fluid using liquid scintillation counter 1209 Rackbeta.

\section{RESULTS AND DISCUSSION}

This study was undertaken in order to check which DNA polymerases are involved in in- duced gene conversion and whether there is any polymerase specificity toward different kinds of DNA damage in this process, as it was established earlier for DNA repair (Wang et al., 1993; Budd \& Campbell, 1995; Hałas et al., 1997; 1999).

Using thermosensitive heteroallelic diploid mutants in genes encoding DNA polymerases $\alpha, \delta$ and $\varepsilon$, we studied the influence of DNA polymerase activity on the process of gene conversion. The rationale for the experiments was adapted from the work of Fabre et al. (1991). Gene conversion was induced by UV irradiation or by treatment with MMS and psoralens. Stationary phase $\left(\mathrm{G}_{0}\right)$ cells were treated with mutagen and incubated in restrictive or permissive conditions (see Materials and Methods).

At the restrictive temperature (permanent incubation at $38^{\circ} \mathrm{C}$ ) DNA polymerase activity is blocked, which inhibits the growth of colonies. Since mutations in the two DNA polymerase alleles are in different sites, the activity of DNA polymerase may be restored by gene conversion. Growth of colonies would be observed only in the situation when the investigated polymerase is not essential for the induced gene conversion. During $6 \mathrm{~h}$ of preincubation at $23^{\circ} \mathrm{C}$ before the shift to $38^{\circ} \mathrm{C}$, the thermosensitive DNA polymerase is active and cells are able to divide at least once. As it is shown in Fig. 1, during $6 \mathrm{~h}$ of incubation at $23^{\circ} \mathrm{C}$ after mutagen treatment a significant level of DNA synthesis was observed for all tested strains. If the investigated DNA polymerase is engaged in gene conversion, the number of convertants appearing after preincubation should be significantly higher than that observed at the restrictive temperature.

Such a procedure was applied for each of three essential polymerase mutants $\alpha, \delta$, and $\varepsilon$ (see Materials and Methods). The survival level after mutagen treatment was determined in parallel by plating diluted aliquots of the cell suspension on YPD plates and incubating at $23^{\circ} \mathrm{C}$. 

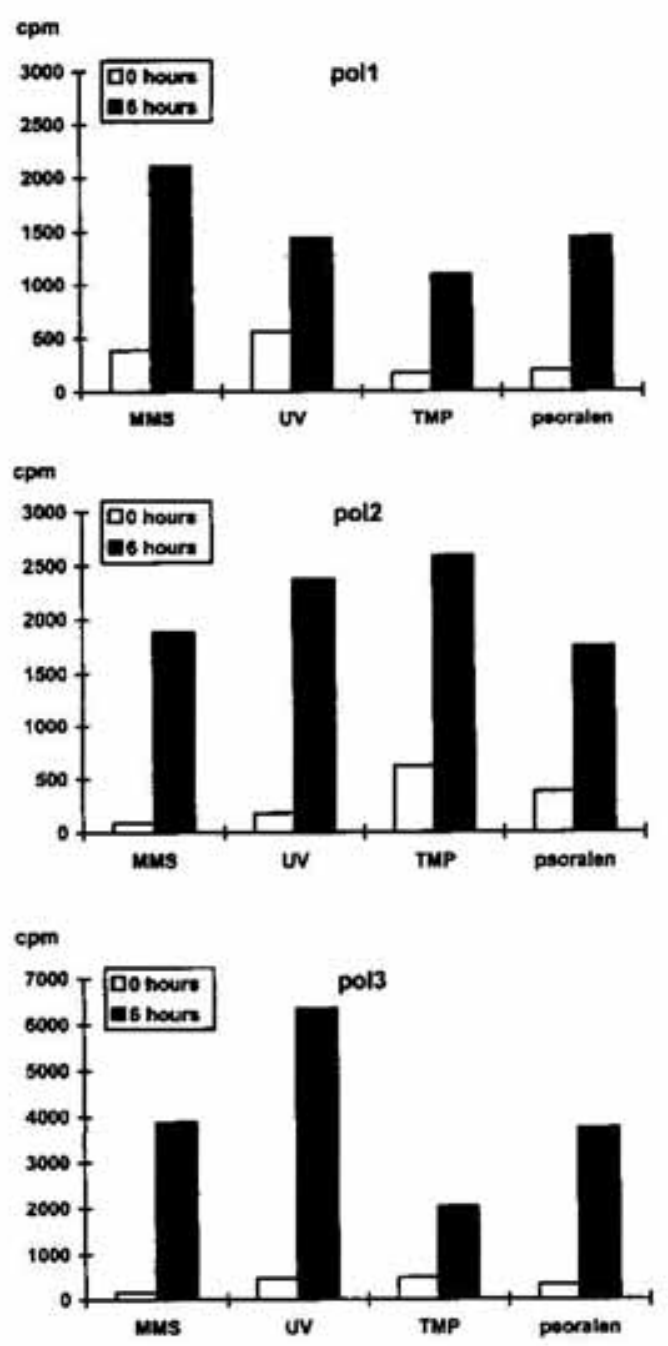

Figure 1. DNA synthesis measured in mutant strains pol1, pol2, pol3 after treatment with maximum dose of mutagen: $(\square)$ synthesis measured immediately after adding an isotope ( $\square$ ) synthesis after $6 \mathrm{~h}$ of incubation at $23^{\circ} \mathrm{C}$.

To be sure that the wild type colonies appearing in the restrictive conditions were real intragenic recombinants (not simple revertants), we performed the same experiments with homoallelic diploids for all used alleles. In this case the observed level of reversion was very low (not shown).

It was not possible to compare results for each tested strain because of different conversion levels at the restrictive temperature. Figure 2 shows that after UV treatment of the pol3 mutant strain at $38^{\circ} \mathrm{C}$ the conversion level differs from that of the pol1 and pol2 strains. Such a relation was also observed for other used mutagens (not shown). To compare the involvement of DNA polymerases in the process of induced gene conversion, not only the level of conversion in permissive conditions but also the ratio between levels at $23^{\circ} \mathrm{C}$ and $38^{\circ} \mathrm{C}$ should be considered. To answer the question if the investigated DNA polymerase is involved in the process of induced gene conversion, we had to find out how many times the induction in permissive conditions is higher in comparison with the induction at the restrictive temperature. Therefore, we normalised levels of recombinants growing in restrictive conditions to the same unit value equal to 1 . It is possible to compare induction levels of convertants growing in permissive conditions after recalculation of each data point from $23^{\circ} \mathrm{C}$ according to the normalised level at the restrictive temperature. For this purpose the normalisation factor $(f)$ representing the ratio of conversion levels obtained at $23^{\circ} \mathrm{C}$ and $38^{\circ} \mathrm{C}$, was calculated according to the formula:

$$
f=\frac{\int_{0}^{t} N_{\text {perm }} d t}{\int_{0}^{t_{\operatorname{man}}} N_{\text {net }} d t}
$$

where $\int_{0}^{t} N_{\text {perm }} d t$, and $\int_{0}^{t} N_{\text {rest }} d t$ are integration areas under the curves of conversion, $N_{\text {perm }}$ and $N_{\text {rest }}$ are number of convertants in permissive and restrictive conditions respectively, $t_{\max }$ is maximal time of mutagen treatment (Fig. 3).

Using this procedure, it is possible to obtain curves of normalised values $N_{\text {perm }}^{\text {norm }}$ by recalculation of each data point. Integration areas under the curves presented in Fig. 4 are represented by numerical values of factors $(f)$ listed in Table 1.

To compare the results for each mutagen quantitatively, the normalisation factors $f$ were transformed to the least integer values (Table 1, data in brackets). 
Frequency of conversion POLI $/ 10$ ' cells
Frequency of conversion POL2 $/ 10^{7}$ cells
Frequency of conversion
POL $3 / 10^{\prime}$ cells

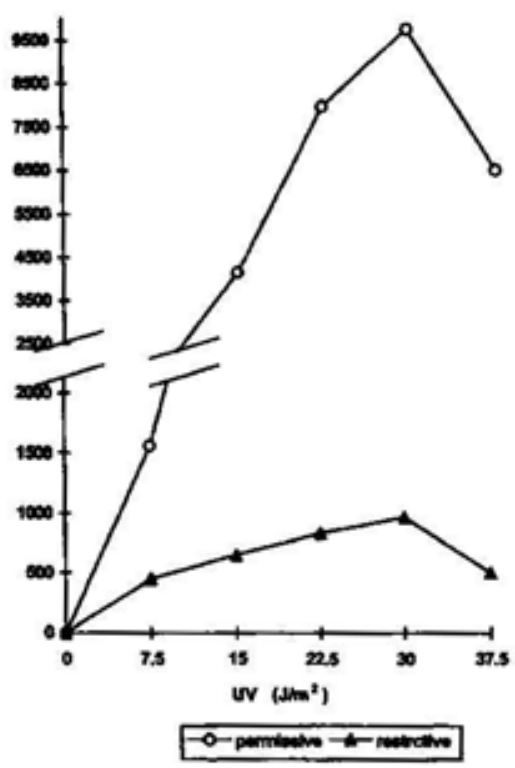

Figure 2. Frequency of conversion in mutant strains pol1, pol2, pol3 irradiated with $\mathrm{UV}$ after $6 \mathrm{~h}$ of incu-

bation at $23^{\circ} \mathrm{C}$ before shift to $38^{\circ} \mathrm{C}(\mathrm{O})$ and incubated constantly at $38^{\circ} \mathrm{C}(\Delta)$.
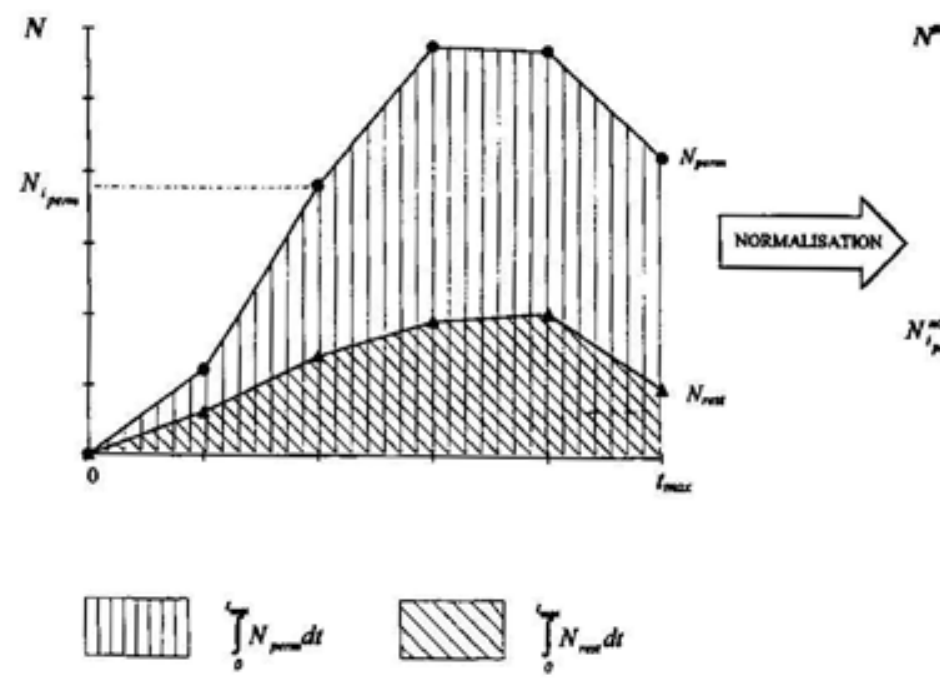

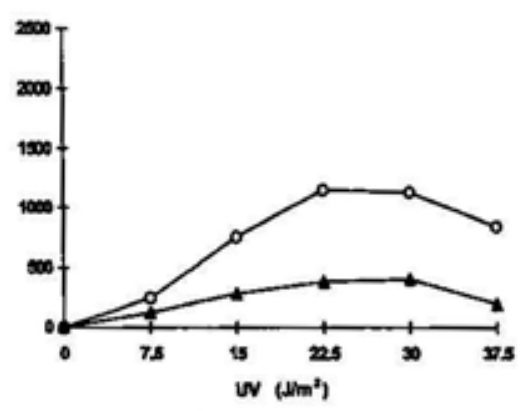

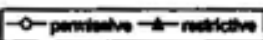

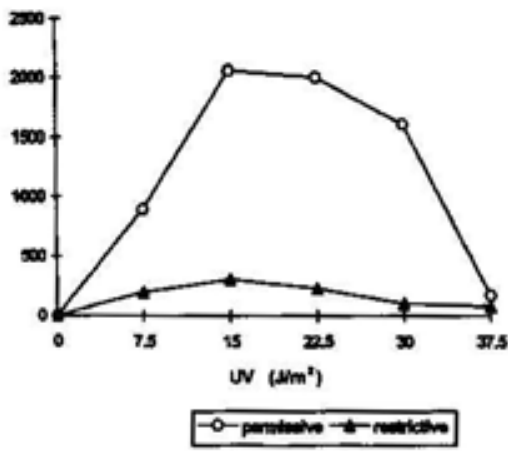


It is known from the literature that DNA polymerases seem to be involved in the repair process of DNA specific to the kind of lesion (Budd et al., 1989; Suszek et al., 1993; Wang et al., 1993; Budd \& Campbell, 1995; Hałas et al., 1997 ; 1999). Bearing in mind this repair specificity of distinct DNA polymerases we undertook our investigations in order to check if there is a specific involvement of DNA polymerases in gene conversion induced by different mutagens. rimidines at one or both ends of the molecule to form monofunctional or bifunctional adducts (crosslinks), respectively (Averbeck, 1994). They are repaired by NER or NER and recombination, respectively.

The mutagens used in our study varied not only in their mode of interaction with DNA, but also in their mutagenic activity. This enabled testing of the influence of the mutagen activity on the conversion level. Survival of strains for maximal mutagen doses was tested

Table 1. Normalisation factors $f$ of conversion curves for HB104 (pol1), AK4 (pol2) and HB69 (pol3) mutants treated with MMS, UV (254 nm), TMP (366 nm), and psoralen $(366 \mathrm{~nm})$. The least integer values of conversion factors are shown in brackets

\begin{tabular}{|c|c|c|c|}
\hline Treatment & $\operatorname{poll}(\alpha)$ & 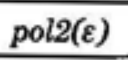 & $\operatorname{pol} 3(\delta)$ \\
\hline MMS & $\begin{array}{l}21.5 \\
{[\sim 3]}\end{array}$ & $\begin{array}{l}7.9 \\
{[\sim 1]}\end{array}$ & $\begin{array}{l}23.6 \\
{[\sim 3]}\end{array}$ \\
\hline $\begin{array}{l}\text { UV } \\
(254 \mathrm{~nm})\end{array}$ & $\begin{array}{l}7.7 \\
{[\sim 3]}\end{array}$ & $\begin{array}{l}2.9 \\
{[\sim 1]}\end{array}$ & $\begin{array}{l}8.5 \\
{[\sim 3]}\end{array}$ \\
\hline $\begin{array}{l}\text { TMP } \\
(366 \mathrm{~nm})\end{array}$ & $\begin{array}{l}6.7 \\
{[\sim 5]}\end{array}$ & $\begin{array}{l}1.4 \\
{[\sim 1]}\end{array}$ & $\begin{array}{l}7.3 \\
{[\sim 5]}\end{array}$ \\
\hline $\begin{array}{l}\text { Psoralen } \\
(366 \mathrm{~nm})\end{array}$ & $\begin{array}{l}6.8 \\
{[\sim 4]}\end{array}$ & $\begin{array}{l}1.8 \\
{[\sim 1]}\end{array}$ & $\begin{array}{l}6.2 \\
{[\sim 3]}\end{array}$ \\
\hline
\end{tabular}

Mutagenic agents used in the study act in a different way. UVC radiation $(254 \mathrm{~nm})$ results in the formation of cyclobutane pyrimidine dimers (mainly $\mathrm{T}-\mathrm{T}$ ) or pyrimidine-pyrimidine (6-4) photoproducts (mainly T-C). These are considered to be bulky, helix-distorting lesions, which can even bend DNA and block DNA polymerases (Chan et al.,1985; Pearlman et al., 1985; Husain et al., 1988). This type of lesion is repaired by the nucleotide excision repair (NER) pathway (Huang et al., 1992).

MMS is one of the monofunctional alkylating agents methylating mainly purines which results in $N^{7}$-methylguanine and $N^{3}$-methyladenine (Singer \& Kuśmierek, 1982). These lesions are repaired by the base excision repair (BER) pathway (Seeberg et al., 1995). Psoralens, like other furocoumarins, intercalate into DNA and after photoactivation by UVA $(364 \mathrm{~nm}$ ) may react with py- in parallel. Percentages of surviving cells are as follows: UV - 35-40\%; MMS - 30-45\%; TMP - 4-14\%; psoralen - 60-65\%.

In our experiments each of the tested mutagens induced gene conversion at a significant level. However, for any particular DNA polymerase no difference in the conversion level with respect to the kind of mutagenic agent was observed (see Fig. 4). In columns of Table 1 representing particular DNA polymerases, the least integer values point to the similar quantitative factor of gene conversion for all mutagens used. This leads to the conclusion that neither of the polymerases is specifically engaged in the process of conversion induced by a particular type of mutagen.

Although no specificity of the DNA polymerases towards the type of lesion was observed, the conversion levels obtained for different polymerases showed significant differences. When comparing the results obtained 


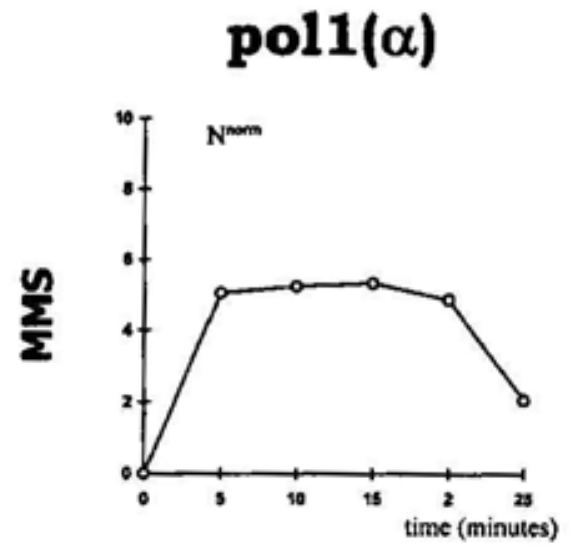

po12(e)
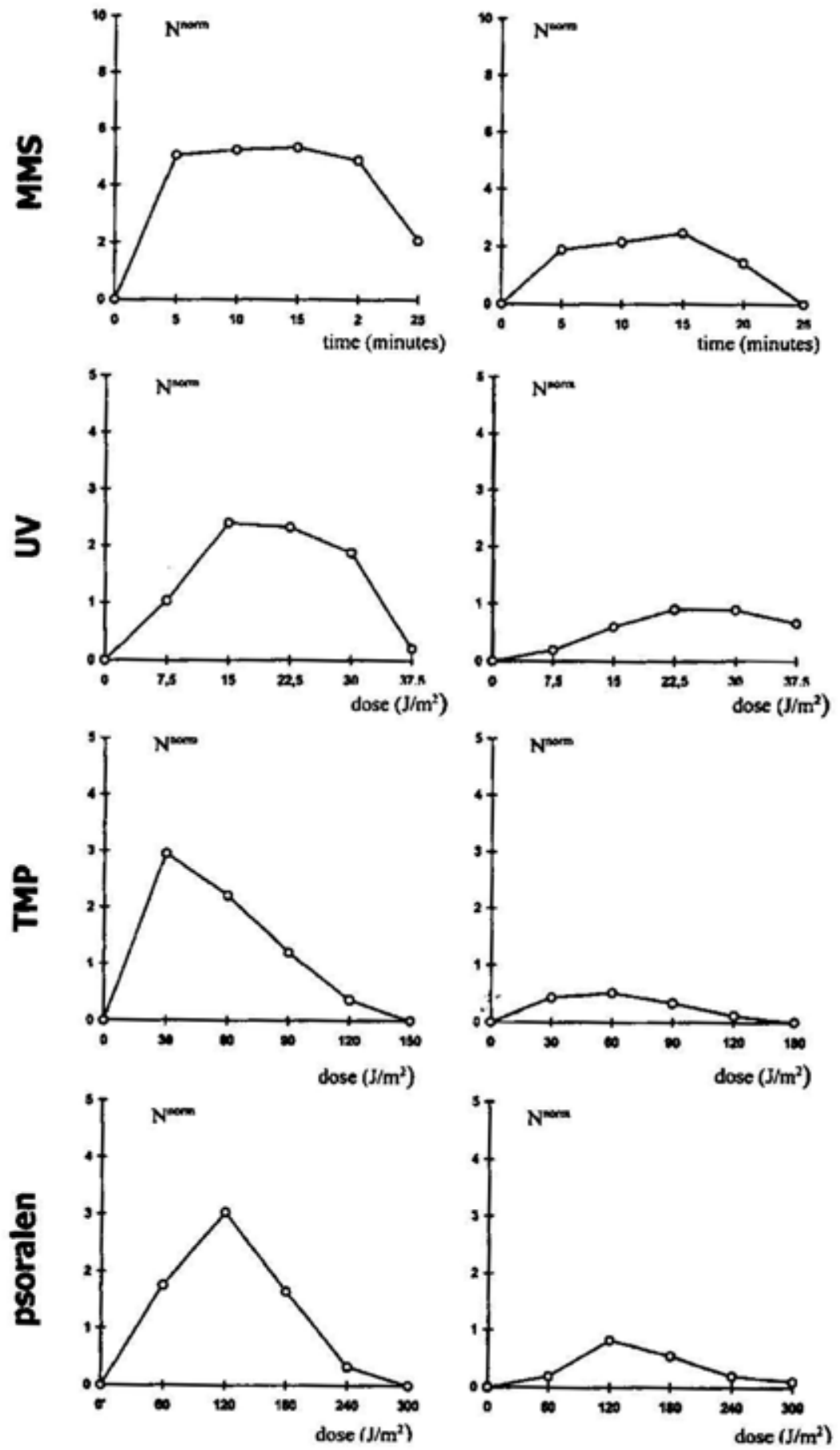

$\operatorname{pol3}(\delta)$
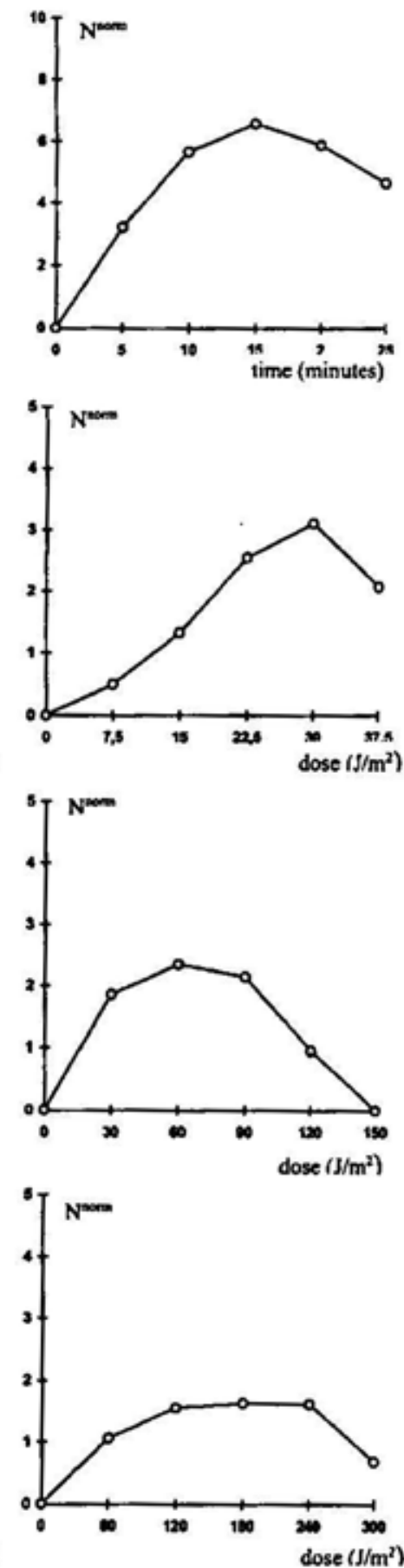

Figure 4. Normalised curves of convertion for mutants HB 104 (pol1), AK4 (pol2) and HB69 (pol3) after treatment with MMS, UV $(254 \mathrm{~nm})$, TMP $(366 \mathrm{~nm})$ and psoralen $(366 \mathrm{~nm})$ growing in permissive conditions. 
for particular polymerase mutants (see Fig. 4) we noticed that the observed gene conversion in the DNA polymerase $\varepsilon$ mutant was lower than in the other mutants. To estimate quantitatively the difference of conversion between mutants used in our experiments, we recalculated the factor $f$ values obtaining the least integer values in respect to the lowest conversion level for pol2 (Table 1, data in brackets). The results for polymerase $\alpha$ and polymerase $\delta$ are quantitatively similar and significantly ( 3 to 5 times) higher than these obtained for polymerase $\varepsilon$.

Our results obtained for the polymerase $\delta$ mutant were similar to those obtained by Fabre et al. (1991). In the plates which were transiently $(6 \mathrm{~h})$ incubated at $23^{\circ} \mathrm{C}$ the cells divided at least once and dose dependent induction of POL3 (CDC2) cells was observed. Treatment with higher doses of mutagens caused a decrease in the number of convertants which was correlated with low cell survival. The induction of convertants for cells treated with UV was high (Fig. 4), similarly as observed by Fabre et al. (1991). The level of conversion induced by MMS, TMP or psoralen was as high as that observed after UV irradiation (Fig. 4). These results confirm the involvement of DNA polymerase $\delta$ in induced gene conversion irrespective of the mutagenic agent used for induction.

For the DNA polymerase $\varepsilon$, required as well for the elongation of DNA during replication the induction of convertants was also observed, but at a low level irrespective of the type of agents used for induction. These results suggest that polymerase $\varepsilon$ is engaged in the process of conversion to a significantly lower extent than polymerase $\delta$. This fact may be due to polymerase $\varepsilon$ acting as a sensor of DNA replication, which coordinates the transcriptional and cell cycle responses to replication blocks (Navas et al., 1995). Our results support the conclusion that two polymerases $\delta$ and $\varepsilon$ can compensate for each other not only during repair of UV-induced lesions (Budd \& Campbell, 1995) but also during recombinational synthesis. However, the results observed for polymerase $\varepsilon$ may also be explained by the leakiness of the tested mutant strain.

The most interesting results concern the involvement of DNA polymerase $\alpha$ in the process of induced gene conversion. We obtained significant differences between the numbers of convertants growing on plates transiently incubated at $23^{\circ} \mathrm{C}$ and incubated continually at $38^{\circ} \mathrm{C}$. The conversion level for pol1 mutant was as high as for pol3 (cdc2) mutant, and was also independent of the kind of mutagen used in the experiment (Fig. 4, Table 1). DNA polymerase $\alpha$ is involved in the first step of replication, extending RNA primers in the replication fork. In Escherichia coli double strand breaks are repaired by a mechanism creating a replication fork (Budd \& Campbell, 1997). By analogy, the formation of a replication fork during repair of double strand breaks in yeast might explain the involvement of DNA polymerase $\alpha$ in gene conversion.

In conclusion, it seems that in gene conversion DNA polymerase $\alpha$ is necessary for extending RNA primers in the replication fork created in the process of recombinational DNA synthesis. DNA polymerase $\delta$ continues DNA synthesis and probably may be substituted by DNA polymerase $\varepsilon$. This would support the theory stating that the overall level of cellular polymerases is a decisive factor for the repair capacity of the cell (Budd \& Campbell, 1997).

We are grateful to Dr. W. Jachymczyk for stimulating discussion and critical comments on the manuscript. Special thanks are due to Dr. H. Baranowska for help in constructing strains.

\section{RE FER E N C ES}

Araki, H., Ropp, P.A., Johnson, A.L., Johnson, L.H., Morrison, A. \& Sugino, A. (1992) DNA polymerase II, the probable homolog of mammalian DNA polymerase $\varepsilon$, replicates chromo- 
somal DNA in the yeast Saccharomyces cerevisiae. EMBO J. 11, 733-740.

Averbeck, D. (1994) Photoaddition by furocoumarins; in Photobiology in Medicine (Jori et al., ed.) pp. 71-98, Plenum Press, New York.

Bauer, G.A., Heller, H.M. \& Burgers, P.M.J. (1988) DNA polymerase III from Saccharomyces cerevisiae. J. Biol. Chem. 263, 917-924.

Blank, A., Kim, B. \& Loeb, L. (1994) DNA polymerase $\delta$ is required for base-excision repair of DNA methylation damage in Saccharomyces cerevisiae. Proc. Nath. Acad. Sci. U.S.A. 91, 9047-9051.

Boulet, A., Simon, M., Faye, G., Bauer, G.A. \& Burgers, P.M.J. (1989) Structure and function of the Saccharomyces cerevisiae $C D C 2$ gene encoding the large subunit of DNA polymerase III. EMBO J. 8, 1849-1854.

Budd, M.E., Wittrupt, K.D., Bailey, J.E. \& Campbell, J.L. (1989) DNA polymerase I is required for premeiotic DNA replication and sporulation but not for X-ray repair in Saccharomyces cerevisiae. Mol. Cell. Biol. 9, 365-376.

Budd, M.E. \& Campbell, J.L. (1993) DNA polymerases $\delta$ and $\varepsilon$ are required for chromosomal replication in Saccharomyces cerevisiae. Mol. Cell. Biol. 13, 496-505.

Budd, M.E. \& Campbell, J.L. (1995) DNA polymerases required for repair of UV-induced damage in Saccharomyces cerevisiae. Mol. Cell. Biol.15, 2173-2179.

Budd, M.E. \& Campbell, J.L. (1997) The roles of the eucaryotic DNA polymerases in DNA repair synthesis. Mutat. Res. 384, 157-167.

Chan, G.L., Doetsch, P.W. \& Haseltine, W.A. (1985) Cyclobutane pyrimidine dimers and (6-4) photoproducts block polymerisation by DNA polymerase I. Biochemistry 24, 57235728.

Fabre, F., Boulet, A. \& Faye, G. (1991) Possible involvement of the yeast POLIII DNA polymerase in induced gene conversion. Mol Gen. Genet. 229, 353-356.

Foiani, M., Martini, F., Gamba, D., Lucchini, G. \& Plevani, P. (1994) The B subunit of the DNA polymerase $\alpha$-primase complex in Saccharo- myces cerevisiae executes an essential function at the initial stage of DNA replication. Mol. Cell. Biol. 14, 923-933.

Hałas, A., Baranowska, H., Policińska, Z. \& Jachymczyk, W.J. (1997) Involvement of the $R E V 3$ gene in the methylated base-xcision repair system. Co-operation of two DNA polymerases, $\delta$ and Rev3p, in the repair of MMS-induced lesions in the DNA of Saccharomyces cerevisiae. Curr. Genet. 31, 292301.

Hałas, A., Policińska, Z., Baranowska, H. \& Jachymczyk, W.J. (1999) The essential DNA polymerases $\delta$ and $\varepsilon$ are involved in repair of UV damaged DNA in the yeast Saccharomyces cerevisiae. Acta Biochim. Polon. 46, 289-298.

Hamatake, R.K., Hasegawa, H., Clark, A.B., Bebenek, K., Kunkel, T.A. \& Sugino, A. (1990) Purification and characterisation of DNA polymerase II from the yeast Saccharomyces cerevisiae. J. Biol. Chem. 265, 4072-4083.

Huang, J.C., Svoboda, D.L., Reardon, J.T. \& Sancar, A. (1992) Human nucleotide excision nuclease removes thymine dimers from DNA by incising the 22nd phosphodiester bond $5^{\prime}$ and the 6th phosphodiester bond 3 to the photodimer. Proc. Natl. Acad. Sci. U.S.A. 89, 3664-3668.

Husain, I., Griffith, J. \& Sancar, A. (1988) Thymine dimers bend DNA. Proc. Natl. Acad. Sci. U.S.A. 85, 2558-2562.

Leem, S.H., Ropp, P.A. \& Sugino, A. (1994) The yeast Saccharomyces cerevisiae DNA polymerase IV-possible involvement in double strand break DNA repair. Nucleic Acids Res. 22, 3011-3017.

Meselson, M.S. \& Radding, C.H. (1975) A general model for genetic recombination. Proc. Natl. Acad. Sci. U.S.A. 72, 358-361.

Morrison, A., Hiroyouki, A., Clark, A.B., Hamatake, R.R. \& Sugino, A. (1990) A third essential DNA polymerase in Saccharomyces cerevisiae. Cell 62, 1143-1151.

Navas, T.A., Zhou, Z. \& Elledge, S.J. (1995) DNA polymerase $\varepsilon$ links the replication machinery to the S phase checkpoint. Cell 80, 29-39. 
Nelson, J.R., Lawrence, C.W. \& Hinkle, D.C. (1996) Thymine-thymine dimer bypass by yeast DNA polymerase zeta. Science 272, 1646-1649.

Pearlman, D.A., Holbrook, S.R., Pirkle, D.H. \& Kim, S.H. (1985) Molecular models for DNA damaged by photoreaction. Science 227, 1304-1308.

Schimizu, K., Santocanale, C., Ropp, P.A., Longhese, M.P., Plevani, P., Lucchini, G. \& Sugino, A. (1993) Purification and characterisation of a new DNA polymerase from budding yeast Saccharomyces cerevisiae J. Biol. Chem. 268, 27148-27153.

Seeberg, E., Eide, L. \& Bjoras, M. (1995) The base excision repair pathway. Trends Biochem. Sci. 20, 391-397.

Singer, B. \& Kuśmierek, J.T. (1982) Chemical mutagenesis. Annu. Rev. Biochem. 51, 655-693.

Sitney, K.C., Budd, M.E. \& Campbell, J.L. (1989) DNA polymerase III, a second essential DNA polymerase, is encoded by the Saccharomyces cerevisiae. Cell 56, 599-605.

Sherman, F., Fink, G.R. \& Lawrence, C.W. (1974) Methods in Yeast Genetics. Cold Spring Harbor
Laboratory Press, Cold Sring Harbor, New York.

Sobol, R.W., Horton, J.K., Kuhn, R., Gu, H., Singhal, R.K., Prasad, R., Rajewsky, K. \& Wilson, S.H. (1996) Requirement of mammalian DNA polymerase-beta in base-xcision repair. Nature 379, 183-186.

Suszek, W., Baranowska, H., Żuk, J. \& Jachymczyk, W.J. (1993) DNA polymerase III is required for DNA repair in Saccharomyces cerevisiae. Curr. Genet. 24, 200-204.

Szostak, J.W., Orr-Weaver, T.L., Rothstein, R.J. \& Stahl, F.W. (1983) The double-strand-break repair model for recombination. Cell 33, 25-35.

Wang, Z., Wu, X. \& Friedberg, E.C. (1993) DNA repair synthesis during base excision repair in vitro is catalysed by DNA polymerase $\varepsilon$ and is influenced by DNA polymerase $\alpha$ and $\delta$ in Saccharomyces cerevisiae. Mol. Cell Biol. 13, 1051-1058.

Wiebauer, K. \& Jiricny, J. (1990) Mismatch-specific thymine DNA glycosylase and DNA polymerase $\beta$ mediate the correction of $\mathrm{G} \cdot \mathrm{T}$ mispairs in nuclear extracts from human cells. Proc. Natl. Acad. Sci. U.S.A. 87, 5842-5845. 